The 'Reality of Revalidation in Practice' (RRiP) project - Experiences of registrants and preparation of students in nursing and midwifery in the United Kingdom: A descriptive exploratory survey

Fisher, Margaret

http://hdl.handle.net/10026.1/14642

10.1016/j.nedt.2019.07.001

Nurse Education Today

Elsevier

All content in PEARL is protected by copyright law. Author manuscripts are made available in accordance with publisher policies. Please cite only the published version using the details provided on the item record or document. In the absence of an open licence (e.g. Creative Commons), permissions for further reuse of content should be sought from the publisher or author. 


\section{THE ‘REALITY OF REVALIDATION IN PRACTICE’ (RRIP) PROJECT - EXPERIENCES OF REGISTRANTS AND PREPARATION OF STUDENTS IN NURSING AND MIDWIFERY IN THE UNITED KINGDOM: A DESCRIPTIVE EXPLORATORY SURVEY}

Fisher, M., Child, J., Williamson, G., Pearce, S., Archer, J., Smethurst, Z-L., Wenman, S. and Griffith, J., 2019. 'The 'Reality of Revalidation in Practice' (RRiP) project - Experiences of registrants and preparation of students in nursing and midwifery in the United Kingdom: A descriptive exploratory survey'. Nurse Education Today, https://doi.org/10.1016/j.nedt.2019.07.001

Date of acceptance: 08/07/2019

Date of on-line publication: 12/07/2019

\section{KEYWORDS}

revalidation; nursing; midwifery; professional; registration; renewal; students; survey

\section{ABSTRACT}

Background: Renewal of healthcare registration or license to practise is becomingly increasingly common, worldwide. Evidence regarding the experience of nursing and midwifery revalidation in the United Kingdom is limited. Preparation of students for the process has not yet been considered in the literature.

Objectives: To explore registrants' experiences of undertaking or supporting colleagues through revalidation. To consider preparation of pre-registration students for this future professional requirement.

Design: A descriptive exploratory study comprising an on-line survey.

Setting: A university in the southwest of England and associated clinical placements. 
Participants: Nursing and Midwifery Council registrants, comprising 40 university staff and 40 clinicians; 36 pre-registration nursing and midwifery students.

Methods: Participation in an anonymous on-line survey was invited via university databases. Descriptive statistical analysis of quantitative data used a combination of software and manual methods. Qualitative data were manually coded and categorised into themes through inductive reasoning.

Findings: Most experiences of revalidation were positive. Reflective discussions resulted in mutual learning, particularly if partners were chosen by the registrant. External scrutiny was welcomed. Some registrants questioned involvement of line managers and alignment with performance review, seeking to avoid a 'tick-box exercise' and conflicts of interest. University staff felt better prepared and more positive than clinicians. Pre-registration curriculum activities preparing students included writing reflections, maintaining portfolios, practice assessment and discussions about the revalidation process. Midwifery students seemed better prepared than nursing peers. Key themes of 'Professional values', 'Preparation', 'Process' and 'Purpose' and a range of positive influences and potential hazards informed development of a conceptual model.

Conclusions: The purpose and process of revalidation is enhanced if confirmation is undertaken by a registered nurse or midwife of the individual's choice. Preparation of students for future revalidation is facilitated by role-modelling of positive attitudes and explicitly linking relevant pre-registration curriculum activities to this process and purpose. 


\section{INTRODUCTION}

Following a series of serious failings in clinical care and leadership in the United Kingdom (UK) health sector (National Health Service England, 2013), a key report recommended that all health professionals undertake revalidation (Francis, 2013). Strengthening of the existing process to reaffirm validity of continued registration was introduced by the Nursing and Midwifery Council in April 2016 (NMC, 2019), but research into this approach to revalidation is currently very limited. The 'Reality of Revalidation in Practice' (RRiP) project was instigated in autumn 2017 to explore registrants' experiences of revalidation and consider preparation of students for this future professional requirement. There will always be a first time for new registrants, but this concept has not yet been considered by the NMC or in the wider literature.

\section{BACKGROUND}

Globally, regulators are mandated to protect public safety by ensuring that healthcare professionals are competent to practise at point of registration and beyond, but these approaches vary. Boulet and van Zanten (2014) explain that regulators in Australia, Mexico and the UK accredit individual academic programmes leading to initial professional registration. Entire educational institutions are approved by regulators in most South American and some Asian and African countries. The importance of maintaining competence beyond initial registration has been highlighted by Casey et al. (2017) in an Irish study, and the American Nurses Credentialing Center's Commission on Accreditation (ANCC, 2012) identified that links between continuing professional development (CPD) and positive patient outcomes in nursing have been demonstrated in several studies. Scales to evaluate competence have been used for 
senior nurses in Japan (Akamine et al., 2013), and as self-assessment tools to facilitate employment of nurses across European Union countries (Cowan et al., 2007). Regulators are increasingly requiring registrants to maintain entitlement to practise through a formal process of renewal; the usual term being 'revalidation', while physicians in Australia and New Zealand and nurses in North America refer to 'recertification' or 'relicensure' (Merkur et al., 2008; National Council of State Boards of Nursing, 2011). Commonly, evidence of practice hours and continuing learning is required, including educational activities, peer and patient feedback and - particularly in medical professions - some form of assessment (Archer et al., 2018).

Every three years, nurses and midwives in the UK are now required to provide evidence for revalidation. The NMC $(2019, \mathrm{p} 6)$ seeks to thereby "encourage a culture of sharing, reflection and improvement" which "strengthens public confidence in the nursing and midwifery professions". Evidence comprises: 450 practice hours (or 900 if registered in both professions), 35 hours of CPD, five sets of feedback relevant to their scope of practice, and five reflective pieces; all of which must be applied to the professional Code. Reflections are discussed with a 'reflective discussion partner' (RDP), who must be an NMC registrant. A 'confirmer', who does not need to be an NMC registrant and is commonly a line manager, affirms that the evidence presented meets the requirements for revalidation. The RDP and confirmer may be the same person, if NMC registered. On completion, the registrant submits an on-line application to maintain their registration; no original documents are required. The NMC (2019) quality assures the process by sampling applications, and may require further evidence as part of 'verification'. 
Current evidence of the experience and effectiveness of NMC revalidation is limited. Interim findings from the first two years of an external evaluation commissioned by the NMC are predominantly quantitative, comprising a longitudinal survey of 4,345 registrants undertaking revalidation (Ipsos MORI Social Research Institute, 2017; 2018). Despite being a national evaluation, only 25 telephone interviews of RDPs and confirmers, and 8 case studies have been conducted. Three peer-reviewed publications specifically discussing revalidation have been identified since its implementation in 2016, two of which have emerged since our study was undertaken. One article described preparation of academic staff (Attenborough, 2017), a small study of 10 academics explored the impact of revalidation on professional identity (Attenborough and Abbott, 2018a), and an analytical paper debated registrant versus employer responsibility for CPD (Lanlehin, 2018). All existing literature has found the revalidation process to be generally positive, with reflective elements particularly valued. The potential for a 'tick-box' approach has, however, been highlighted. Contribution to the impact on public confidence has been questioned.

The survey presented was conducted by a research team based at a university in southwest England, comprising academic nursing and midwifery staff, a nursing student and the lead of the national evaluation of medical revalidation. The aim was twofold: to explore registrants' experiences of undertaking or supporting colleagues through revalidation, and to consider preparation of students for this future professional requirement. 


\section{METHODS}

A descriptive exploratory approach was adopted, purposefully selecting representation from a wide range of participants in a university and associated clinical settings who would best inform the research aims (Cresswell and Poth, 2018). A study undertaken by Gill et al. (2013) found that the on-line platform 'SurveyMonkey' proved an efficient method of data collection in health research. The team therefore used this software, dividing the survey into three sections (Figure 1). Throughout the survey, participants were invited to expand on quantitative responses through free text qualitative comments.

Interactive collaboration to inform research design is recommended by Cresswell and Poth (2018). Roundtable discussions at an earlier local stakeholder event therefore informed development of two research tools used in the third section. These comprised check-lists of 'activities' relevant to preparation for revalidation. One related to pre-registration nursing and midwifery curricula, such as reflections and portfolios. A modified list focused on the post-qualification context.

Representatives from the stakeholder groups tested functionality and quality of the survey questions in a pilot. At their suggestion, additions were made to the above research tools. Respondents confirmed that the survey was easily completed between 5 and 20 minutes, and that they were appropriately diverted to relevant sections. All pilot data were excluded from the main survey. 


\begin{tabular}{|l|l|}
\hline Section 1: & $\begin{array}{l}\text { - Due date } \\
\text { - Preparation } \\
\text { Experience of } \\
\text { undertaking }\end{array}$ \\
- Experience of reflective discussion \\
- Experience of confirmation \\
- Achievement of the NMC purpose of revalidation \\
- Proposed changes
\end{tabular}

Figure 1: Survey structure and question topics

\subsection{Participants and ethical considerations:}

The project was approved by the University Ethics Committee. A convenience sample of participants based at the university included NMC-registered staff and third year students who were undertaking a programme leading to registration as a nurse or midwife. Qualified staff undertaking further studies, alumni and attendees at local revalidation events who had expressed an interest in participating in this research represented clinicians. Prospective participants were accessed via university databases and there were no exclusion criteria. Individuals were only able to complete the survey once. Participation was voluntary; a 'submit' button confirmed consent to include data at the end of the survey, but respondents were able to exit at any stage. To ensure anonymity, internet provider addresses were automatically removed at point of entry and password-protected access to original data was limited to the principal investigator. To avoid bias, participant codes were only applied to qualitative data on 
completion of analysis (e.g.: SM3 = student midwife, RNC4 = registered nurse clinician).

\subsection{Data collection and analysis:}

Administrative staff circulated the invitations and survey link via university or work email addresses. This facilitated access to participants, while avoiding researcher bias and maintaining confidentiality. A reminder was circulated a fortnight later. It is not possible to state the response rate as it was unknown how many contacts were still current or duplicated on other lists. Anonymised responses were filtered via the survey software and manually checked on a spreadsheet. Data were cleansed and re-filtered for nine nursing students who identified their base as a clinical area rather than the university, resulting in initial mis-categorisation as registrants.

Although some comparisons were made within and between categories of participants, correlational tests were not performed as determining statistical significance was not the aim of the study, and the total population was unknown. Descriptive statistical analysis of quantitative data was undertaken; totals are presented as numbers and percentages. Satisfaction and confidence levels were determined through nominal scales. Frequencies of responses in section three were ranked by the researchers.

Thematic analysis examined the patterns in qualitative data which were initially manually coded by individual researchers. Cresswell and Poth (2018) advocate structural corroboration to promote reliability of interpretation. Inter-coding and 
categorisation of themes, through inductive reasoning, were therefore subsequently agreed in a team meeting.

\section{FINDINGS}

A total of 116 participants responded, comprising 40 university staff, 40 clinicians and 36 pre-registration students. Professional categorisation and total respondents to each section are shown in Table 1. Quantitative and qualitative findings are presented according to the survey sections. Coding is shown in italics; participant quotes are included as examples of qualitative responses.

\begin{tabular}{|c|c|c|c|}
\hline Categorisation & $\begin{array}{l}\text { University } \\
\text { staff }\end{array}$ & Clinicians & $\begin{array}{l}\text { Pre-registration } \\
\text { Students (third year) }\end{array}$ \\
\hline Total participants: $\mathrm{N}=116$ & 40 (34.5\%) & $40(34.5 \%)$ & $36(31 \%)$ \\
\hline Nursing registrants: $\mathrm{N}=69$ & 33 & 36 & N/A \\
\hline $\begin{array}{l}\text { Midwifery registrants: } \mathrm{N}=11 \\
\text { *Included } 4 \text { dual registered participants, with } \\
\text { midwifery the main registration under which they } \\
\text { were practising: } 1 \text { university staff, } 3 \text { clinicians }\end{array}$ & $7^{*}$ & $4^{*}$ & N/A \\
\hline Nursing registration (pending): $\mathrm{N}=31$ & N/A & $\mathrm{N} / \mathrm{A}$ & 31 \\
\hline Midwifery registration (pending): $\mathrm{N}=5$ & N/A & N/A & 5 \\
\hline $\begin{array}{l}\text { Respondents to Section } 1 \text { (see Fig. } 1 \text { ): } \mathrm{N}=44 \\
\text { (4.1: Experience of undertaking revalidation) }\end{array}$ & $\begin{array}{l}25 \\
19 \text { nursing } \\
6 \text { midwifery }\end{array}$ & $\begin{array}{l}19 \\
16 \text { nursing } \\
3 \text { midwifery }\end{array}$ & $\mathrm{N} / \mathrm{A}$ \\
\hline $\begin{array}{l}\text { Respondents to Section } 2 \text { (see Fig.1) } \\
\text { (4.2: Experience of supporting colleagues) }\end{array}$ & & & \\
\hline $\mathrm{N}=20$ Reflective discussion partners (RDP) & 11 & 9 & {$[10-$ anomaly] } \\
\hline $\mathrm{N}=13$ Confirmers & 8 & 5 & [1 - anomaly] \\
\hline $\begin{array}{l}\text { Respondents to Section } 3 \text { (see Fig.1) } \\
\text { (4.3: Preparation of students and registrants) } \\
\mathrm{N}=\text { variable }- \text { see Tables } 2,3,4,5\end{array}$ & Variable & Variable & Variable \\
\hline
\end{tabular}




\subsection{Experience of undertaking revalidation:}

All registrants and final year midwifery students knew when they would need to revalidate, but not all final year nursing students were sure. Of the 80 registrants, $55 \%$ $(\mathrm{N}=44)$ had undertaken revalidation and completed this section (see Table 1). Categories comprised 25 university staff, 19 clinicians, 35 nurses and 9 midwives (of whom 3 were also registered nurses). Percentages are calculated according to the sample sizes in each category, unless indicated otherwise.

A trend was noted towards university staff and midwifery registrants feeling better prepared than their clinical and nursing colleagues respectively. Of the 44 registrants, $60 \%$ university staff $(n=15), 26.3 \%$ clinicians $(n=5), 77.8 \%$ midwifery $(n=7)$ and $37.1 \%$ $(n=13)$ nursing participants stated that they felt 'very well prepared'. More university participants sought and received support than clinicians (84\%, $n=21$ versus $52.6 \%$, $\mathrm{n}=10) ; 13$ registrants $(29.5 \%)$ had not accessed this. 'People' providing support included line managers, organisational revalidation leads and supervisors of midwifery. Participants also accessed NMC guidance, attended employer workshops and viewed examples from colleagues ('learning from others/ experience'). Challenges included 'time' to prepare documentation and difficulty in arranging meetings with confirmers.

Of the 44 registrants undertaking revalidation, 35 (79.6\%) experienced concurrent reflective and confirmation discussions. A code of 'choice' was identified; some participants stated that they were able to select their RDPs and confirmers, while others were enforced through 'lack of opportunity' or local policies. Registrants expressed a preference for individuals who understood the registrant's scope of 
practice, although five (11.4\%) stated that line managers were too busy or had another focus. Some deliberately chose 'trusted' colleagues with a different perspective or who were external to their place of work, 'appreciating differences':

“We knew each other well and it was 'safe'. I knew I could be totally honest. It was also helpful as she was external to my place of work, so there was no hidden agenda." (RMNU3)

Revalidation could be used as a lever to gain further CPD opportunities and peer feedback was valued. Collegiate reflective discussion was perceived as particularly beneficial; 'learning from others' through open, honest and frank conversations promoted development:

"It encourages reflection in a more formal and productive manner rather than the more stagnant rumination which has become the default position of many older nurses." (RNC24)

'Professionalism and accountability' was a frequently recurring code. This included comments about taking the process seriously, selecting evidence reflecting the full range of participants' roles, maintaining a professional focus and enjoying being challenged. A desire for 'governance/ scrutiny' of the process, ensuring an "equitable and authentic approach" (RMU4) and avoiding 'inconsistency' was expressed, and some participants were disappointed that they were not required to submit original evidence to the NMC.

Although all participants expressed satisfaction with the reflective discussion, nominal scales indicated that university staff were often more satisfied than clinicians, with $88 \%$ 
$(\mathrm{n}=22 ; \mathrm{N}=25)$ stating they were 'positive' or 'very positive' about the experience, compared with $68.4 \%(\mathrm{n}=13 ; \mathrm{N}=19)$ clinicians. One participant had "already closed the reflection" (RNC16), so did not gain further learning, and four (9.1\%) expressed concerns about a 'tick-box' process:

"Just felt it was going through the motions." (RAN47)

Six (13.6\%) participants exercised 'choice' by holding separate reflective and confirmation discussions. An interested and supportive confirmer who understood and explained the process was considered particularly important. Some participants expressed concerns about potential conflicts of interest:

"I believe that there is a risk that there can be a conflict of interest between an employer being a confirmer particularly in areas where there are staff shortages." (RMU6)

When all participants who had revalidated $(\mathrm{N}=44)$ were asked whether they considered that the NMC purpose had been achieved, responses were mixed; $54.6 \%$ $(n=24)$ saying that this had been 'fully achieved', $31.8 \%(n=14)$ 'partially achieved' and $13.7 \%(n=6)$ 'not achieved'. There were doubts about the impact of revalidation on public confidence. Negative comparisons were made with midwifery supervision, which was perceived as having been a more valuable process. This statutory requirement included annual reflective discussions and documentation audit, but was discontinued by the regulatory body shortly before our survey took place (NMC, 2017). Concerns about the potential for revalidation to be a 'tick-box' exercise were again highlighted. It was, however, suggested that it was "a step in the right direction" (RNU5), with potential for positive influences on practice and patient care. The focus 
on reflective discussion, application of the NMC Code and increased study opportunities were beneficial:

"Because of revalidation there has been a huge increase in availability of study days and learning new information which is beneficial for practice and in turn patient care." (RNC34)

Thirty-one participants $(70.5 \% ; \mathrm{N}=44)$ indicated that they were 'happy with how things went and would not make any changes' for their next revalidation. Thirteen $(29.5 \%)$ would, in future, keep up to date with collating evidence, write reflections as they went along and ensure that they chose someone to be their RDP and confirmer with whom they could be totally professionally open. Twenty-three (52.3\%) had already made changes to practice, including developing action plans, being more mindful of opportunities to reflect and share experiences with colleagues and actively seeking peer review. These responses were coded as 'professionalism and accountability'.

\subsection{Experience of supporting colleagues:}

Although 30 participants stated that they had acted as a reflective discussion partner, 10 were pre-registration students; one of whom said they had also been a confirmer. This meant that they erroneously completed this section rather than being redirected, as was intended for students. The student data were excluded and this misconception is discussed in section 5. Of total registrants $(\mathrm{N}=80), 20(25 \%)$ had acted as RDPs and $13(16.3 \%)$ as confirmers (see Table 1).

Registrants felt empowered by supporting their colleagues ('respect/ being valued'). They highlighted the importance of listening carefully and recognising that there was 
no right or wrong way of approaching reflection, provided that the NMC Code was applied. They valued 'learning from others', commenting that reflective discussions promoted mutual learning. They also felt that supporting a colleague with whom they did not normally work facilitated objectivity, and found it beneficial to discover the variety of roles and practice contexts, 'appreciating differences':

"It was very interesting to have insight into the experience of my peer, she had the same job role as myself but in a completely different ward environment. We had shared issues and I valued the opportunity to discuss strategies and experiences." (RNC24)

Participants highlighted good practice in scheduling adequate 'time' for the meeting and suggested it was helpful to map documentation against the NMC Code in advance. Responses concurred with the NMC (2019) principle that the agenda should be driven by the registrant, with RDPs and confirmers promoting safety and support by being non-judgemental and open, enabling constructive discussion:

"Ensure protected time, ensure agenda is driven by the registrant seeking revalidation, ensure registrant understands the process and why it is in place. The experience must not be just a paper exercise." (RMU4)

Challenges highlighted by participants included: registrants being reluctant to prepare or leaving this to the last minute, inconsideration regarding other demands, inadequate insight and reflection, inappropriate evidence, failure to follow guidelines and one request for a confirmer to complete the registrant's documentation. Three $(15 \%, N=20)$ stated that the confirmer should not be a line manager but a respected colleague noting that confirmation could potentially become a 'tick-box' exercise if the reflective 
discussion had been undertaken separately. 'Preparation', 'workload', 'choice', 'respect/ being valued' and 'professionalism and accountability' were identified as codes.

\subsection{Preparation of students and registrants:}

All midwifery students $(\mathrm{N}=5 ; 100 \%)$ felt 'fairly' or 'very well prepared' for their future revalidation. Of 31 nursing students, only $18(58.1 \%)$ responded to this question. Of $\mathrm{N}=18$, none felt 'very well prepared', $13(72.2 \%)$ 'fairly well prepared' and $5(27.8 \%)$ 'not at all prepared'. 'Preparation' included: reading the NMC website, attending a revalidation event or session at university, discussing experiences with registrants and completing portfolios or reflections. Several nursing students commented that revalidation had not been discussed in their course or placements.

Participants were asked to indicate which 'activities' in the existing pre-registration curriculum, from a list of 18 , helped prepare students for revalidation (Table 2). A total of 88 responded $(75.9 \% ; \mathrm{N}=116)$. Highest ranking was attributed to those 'activities' which contributed to the development of reflective skills, followed by practice assessment. 'Developing a professional approach to being assessed by others' and 'self-assessment' were ranked respectively higher for midwifery than nursing participants. Structured activities were consistently ranked lowest, including 'regular drip-feeding' during theory, 'a specific taught session' and 'structured reflective discussion'. Participants additionally identified familiarisation with the NMC website and clear lectures outlining revalidation. 


\begin{tabular}{|c|c|c|c|c|c|c|c|}
\hline $\begin{array}{l}\text { Overall } \\
\text { ranking }\end{array}$ & Activity & & $\begin{array}{l}\text { Jerall } \\
\text { ponses } \\
=88)\end{array}$ & & $\begin{array}{l}\text { Nursing } \\
\text { sponses and } \\
\text { ranking } \\
(\mathrm{N}=73)\end{array}$ & & $\begin{array}{l}\text { Midwifery } \\
\text { sponses and } \\
\text { ranking } \\
(\mathrm{N}=15)\end{array}$ \\
\hline 1 & Writing reflections & 84 & $95.5 \%$ & 1 & $69=94.5 \%$ & 2 & $14=93.3 \%$ \\
\hline 2 & Developing reflective thinking skills & 83 & $94.3 \%$ & 1 & $69=94.5 \%$ & 2 & $14=93.3 \%$ \\
\hline 2 & Keeping a portfolio or e-portfolio & 83 & $94.3 \%$ & 3 & $68=93.2 \%$ & 1 & $15=100 \%$ \\
\hline 4 & $\begin{array}{l}\text { Gaining feedback from others to contribute } \\
\text { to practice assessment }\end{array}$ & 73 & $82 \%$ & 4 & $59=80.8 \%$ & 2 & $14=93.3 \%$ \\
\hline 5 & Being assessed by others in practice & 69 & $78.4 \%$ & 4 & $59=80.8 \%$ & 11 & $10=66.7 \%$ \\
\hline 6 & $\begin{array}{l}\text { Developing a positive approach to lifelong } \\
\text { learning }\end{array}$ & 68 & $77.3 \%$ & 6 & $55=75.3 \%$ & 6 & $13=86.7 \%$ \\
\hline 7 & $\begin{array}{l}\text { Developing a professional approach to } \\
\text { being assessed by others }\end{array}$ & 67 & $76.1 \%$ & 8 & $53=72.6 \%$ & 2 & $14=93.3 \%$ \\
\hline 8 & $\begin{array}{l}\text { Including service-user feedback in the } \\
\text { curriculum }\end{array}$ & 65 & $73.9 \%$ & 6 & $55=75.3 \%$ & 11 & $10=66.7 \%$ \\
\hline 8 & NMC proficiencies/ competencies & 65 & $73.9 \%$ & 8 & $53=72.6 \%$ & 7 & $12=80 \%$ \\
\hline 10 & $\begin{array}{l}\text { Learning about evidence-based practice/ } \\
\text { research }\end{array}$ & 64 & $72.7 \%$ & 10 & $52=71.2 \%$ & 7 & $12=80 \%$ \\
\hline 11 & Using the NMC Code in classroom sessions & 59 & $67.1 \%$ & 11 & $48=65.8 \%$ & 10 & $11=73.3 \%$ \\
\hline 12 & $\begin{array}{l}\text { Undertaking self-assessment formally or } \\
\text { informally as part of practice assessment }\end{array}$ & 58 & $65.9 \%$ & 12 & $46=63 \%$ & 7 & $12=80 \%$ \\
\hline 13 & $\begin{array}{l}\text { Role-modelling by/ discussion with mentors } \\
\text { and others in practice about revalidation }\end{array}$ & 49 & $55.7 \%$ & 13 & $40=54.8 \%$ & 13 & $9=60 \%$ \\
\hline 14 & $\begin{array}{l}\text { Discussion with (student) peers about } \\
\text { revalidation }\end{array}$ & 39 & $44.3 \%$ & 14 & $33=45.2 \%$ & 10 & $6=40 \%$ \\
\hline 15 & $\begin{array}{l}\text { Participation in Schwartz Rounds or other } \\
\text { structured reflective discussion }\end{array}$ & 36 & $40.9 \%$ & 15 & $27=37 \%$ & 13 & $9=60 \%$ \\
\hline 16 & $\begin{array}{l}\text { A specific taught session/s or workshop } \\
\text { about revalidation }\end{array}$ & 33 & $37.5 \%$ & 16 & $26=35.6 \%$ & 16 & $7=46.7 \%$ \\
\hline 17 & $\begin{array}{l}\text { Regular 'drip-feeding' of the importance/ } \\
\text { process of revalidation during relevant } \\
\text { theory sessions }\end{array}$ & 32 & $36.4 \%$ & 17 & $24=32.9 \%$ & 15 & $8=53.3 \%$ \\
\hline 18 & $\begin{array}{l}\text { Other activities (qualitative comments), } \\
\text { including: } \\
\text { - Familiarisation with NMC web- } \\
\text { page } \\
\text { - Clear lectures outlining what } \\
\text { revalidation is }\end{array}$ & 6 & $6.8 \%$ & 18 & $4=5.5 \%$ & 17 & $2=13.3 \%$ \\
\hline
\end{tabular}

Table 2: Ranking of existing activities in curricula, according to profession

Participants were next asked to identify from the same list 'What additional activities should be introduced to help pre-registration students prepare for revalidation?' (Table 3). Eighty-seven participants contributed (75\%; N=116). Minimal additions were identified by midwifery respondents, but many were selected by nursing participants. 
Although many 'activities' already existed in curricula, it was suggested that lack of knowledge of the process meant that links were not readily created:

"I believe my degree course has equipped me with the necessary skills to be able to revalidate. I do not know the process of revalidation, if I were more aware of the process I could simply continue the way I have been taught throughout practice. However, this is likely to falter now as I have no clear awareness of the process I should be following." (SN2).

\begin{tabular}{|c|c|c|c|c|c|c|c|}
\hline $\begin{array}{l}\text { Overall } \\
\text { ranking }\end{array}$ & Activity & & $\begin{array}{l}\text { Jerall } \\
\text { oonses } \\
=87)\end{array}$ & & $\begin{array}{l}\text { Nursing } \\
\text { sponses and } \\
\text { ranking } \\
(\mathrm{N}=73)\end{array}$ & & $\begin{array}{l}\text { Midwifery } \\
\text { sponses and } \\
\text { ranking } \\
(\mathrm{N}=14)\end{array}$ \\
\hline 1 & $\begin{array}{l}\text { No additions - all listed in previous question as } \\
\text { already included in the curriculum }\end{array}$ & 37 & $42.5 \%$ & 1 & $28=38.4 \%$ & 1 & $10=71.4 \%$ \\
\hline 2 & $\begin{array}{l}\text { A specific taught session/s or workshop about } \\
\text { revalidation }\end{array}$ & 28 & $32.2 \%$ & 2 & $27=37 \%$ & 3 & $1=7.1 \%$ \\
\hline 3 & $\begin{array}{l}\text { Role-modelling by/ discussion with mentors and } \\
\text { others in practice about revalidation }\end{array}$ & 17 & $19.6 \%$ & 3 & $17=23.3 \%$ & 0 & 0 \\
\hline 4 & $\begin{array}{l}\text { Regular 'drip-feeding' of the importance/ } \\
\text { process of revalidation during relevant theory } \\
\text { sessions }\end{array}$ & 14 & $16.1 \%$ & 4 & $14=19.2 \%$ & 0 & 0 \\
\hline 5 & $\begin{array}{l}\text { Discussion with (student) peers about } \\
\text { revalidation }\end{array}$ & 12 & $13.8 \%$ & 5 & $11=15.1 \%$ & 3 & $1=7.1 \%$ \\
\hline 6 & Developing reflective thinking skills & 9 & $10.3 \%$ & 6 & $9=12.3 \%$ & 0 & 0 \\
\hline 7 & $\begin{array}{l}\text { Other suggestions (qualitative comments), } \\
\text { including: } \\
\text { - Mock revalidation exercise/ reflective } \\
\text { discussions/ confirmations eg: in year } 3 \\
\text { (X2) } \\
\text { - Use of professional websites, CPD } \\
\text { activities and journals eg: RCM, RCN } \\
\text { - Attending NMC workshops } \\
\text { - More discussion in preceptorship } \\
\text { period }\end{array}$ & 7 & $8 \%$ & 13 & $4=5.5 \%$ & 2 & $3=21.4 \%$ \\
\hline 8 & Writing reflections & 6 & $6.9 \%$ & 7 & $6=8.2 \%$ & 0 & 0 \\
\hline 8 & $\begin{array}{l}\text { Developing a positive approach to lifelong } \\
\text { learning }\end{array}$ & 6 & $6.9 \%$ & 9 & $5=6.9 \%$ & 3 & $1=7.1 \%$ \\
\hline 8 & Using the NMC Code in classroom sessions & 6 & $6.9 \%$ & 7 & $6=8.2 \%$ & 0 & 0 \\
\hline 8 & $\begin{array}{l}\text { Participation in Schwartz Rounds or other } \\
\text { structured reflective discussion }\end{array}$ & 6 & $6.9 \%$ & 9 & $5=6.9 \%$ & 3 & $1=7.1 \%$ \\
\hline 12 & $\begin{array}{l}\text { Gaining feedback from others to contribute to } \\
\text { practice assessment }\end{array}$ & 5 & $5.7 \%$ & 9 & $5=6.9 \%$ & 0 & 0 \\
\hline 12 & $\begin{array}{l}\text { Developing a professional approach to being } \\
\text { assessed by others }\end{array}$ & 5 & $5.7 \%$ & 9 & $5=6.9 \%$ & 0 & 0 \\
\hline 12 & NMC proficiencies/ competencies & 5 & $5.7 \%$ & 13 & $4=5.5 \%$ & 3 & $1=7.1 \%$ \\
\hline 15 & Being assessed by others in practice & 4 & $4.6 \%$ & 15 & $3=4.1 \%$ & 3 & $1=7.1 \%$ \\
\hline 16 & Keeping a portfolio or e-portfolio & 3 & $3.4 \%$ & 15 & $3=4.1 \%$ & 0 & 0 \\
\hline 16 & Including service-user feedback in the curriculum & 3 & $3.4 \%$ & 15 & $3=4.1 \%$ & 0 & 0 \\
\hline
\end{tabular}




\begin{tabular}{|l|l|lllllll}
\hline 16 & $\begin{array}{l}\text { Undertaking self-assessment formally or } \\
\text { informally as part of practice assessment }\end{array}$ & $\mathbf{3}$ & $\mathbf{3 . 4 \%}$ & 15 & $3=4.1 \%$ & 0 & 0 \\
\hline $\mathbf{1 9}$ & $\begin{array}{l}\text { Learning about evidence-based practice/ } \\
\text { research }\end{array}$ & $\mathbf{1}$ & $\mathbf{1 . 1 \%}$ & 19 & $1=0.01 \%$ & 0 & 0 \\
\hline
\end{tabular}

Table 3: Ranking of activities to introduce to curricula, according to profession

From the list of 'activities' relevant to registrants, participants were asked to identify those they considered most useful in preparation for revalidation; 100 responded (86.2\%; $\mathrm{N}=116)$. 'Protected CPD time' was ranked highest, closely followed by 'keeping a portfolio' and 'gaining feedback from others'. Key differences in ranking were noted between midwifery and nursing for 'developing a professional approach to being assessed by others', and 'having a named lead for revalidation' (Table 4).

\begin{tabular}{|c|c|c|c|c|c|c|c|}
\hline \multicolumn{2}{|c|}{$\begin{array}{l}\text { Overall } \\
\text { ranking }\end{array}$} & \multicolumn{2}{|c|}{$\begin{array}{l}\text { Overall } \\
\text { responses } \\
(\mathrm{N}=100)\end{array}$} & \multicolumn{2}{|c|}{$\begin{array}{l}\text { Nursing } \\
\text { responses and } \\
\text { ranking } \\
(\mathrm{N}=84)\end{array}$} & \multicolumn{2}{|c|}{$\begin{array}{l}\text { Midwifery } \\
\text { responses and } \\
\text { ranking } \\
(\mathrm{N}=16)\end{array}$} \\
\hline 1 & Protected CPD time & 79 & $79 \%$ & 1 & $65=77.4 \%$ & 1 & $14=87.5 \%$ \\
\hline 2 & Keeping a portfolio or e-portfolio & 75 & $75 \%$ & 2 & $64=76.2 \%$ & 3 & $11=68.8 \%$ \\
\hline 3 & $\begin{array}{l}\text { Gaining feedback from others to contribute to } \\
\text { practice assessment }\end{array}$ & 70 & $70 \%$ & 3 & $58=69 \%$ & 2 & $12=75 \%$ \\
\hline 4 & Writing reflections & 67 & $67 \%$ & 5 & $56=66.7 \%$ & 3 & $11=68.8 \%$ \\
\hline 4 & $\begin{array}{l}\text { Communication about revalidation internally } \\
\text { in the organisation }\end{array}$ & 67 & $67 \%$ & 4 & $57=67.9 \%$ & 9 & $10=62.5 \%$ \\
\hline 6 & Developing reflective thinking skills & 66 & $66 \%$ & 7 & $55=65.5 \%$ & 3 & $11=68.8 \%$ \\
\hline 7 & $\begin{array}{l}\text { Developing a positive approach to lifelong } \\
\text { learning }\end{array}$ & 63 & $63 \%$ & 8 & $52=61.9 \%$ & 3 & $11=68.8 \%$ \\
\hline 8 & $\begin{array}{l}\text { Discussions with colleagues about } \\
\text { revalidation }\end{array}$ & 62 & $62 \%$ & 9 & $51=60.7 \%$ & 3 & $11=68.8 \%$ \\
\hline 8 & $\begin{array}{l}\text { Having a named lead for revalidation in the } \\
\text { organisation }\end{array}$ & 62 & $62 \%$ & 5 & $56=66.7 \%$ & 18 & $6=37.5 \%$ \\
\hline 10 & $\begin{array}{l}\text { Preparation sessions for those who wish to } \\
\text { act as reflective discussion partners/ } \\
\text { confirmers }\end{array}$ & 61 & $61 \%$ & 9 & $51=60.7 \%$ & 9 & $10=62.5 \%$ \\
\hline 11 & NMC provided information (websites/ emails) & 58 & $58 \%$ & 11 & $49=58.3 \%$ & 13 & $9=56.3 \%$ \\
\hline 12 & $\begin{array}{l}\text { A specific taught session/s or workshop about } \\
\text { revalidation }\end{array}$ & 53 & $53 \%$ & 12 & $44=52.4 \%$ & 13 & $9=56.3 \%$ \\
\hline 13 & $\begin{array}{l}\text { Developing a professional approach to being } \\
\text { assessed by others }\end{array}$ & 52 & $52 \%$ & 13 & $41=48.8 \%$ & 3 & $11=68.8 \%$ \\
\hline 14 & $\begin{array}{l}\text { 'Open door policy' to the person who will be } \\
\text { the reflective discussion partner/ confirmer }\end{array}$ & 51 & $51 \%$ & 13 & $41=48.8 \%$ & 9 & $10=62.5 \%$ \\
\hline 15 & $\begin{array}{l}\text { Learning about evidence-based practice/ } \\
\text { research }\end{array}$ & 49 & $49 \%$ & 13 & $41=48.8 \%$ & 16 & $8=50 \%$ \\
\hline 16 & $\begin{array}{l}\text { Undertaking self-assessment formally or } \\
\text { informally as part of practice assessment }\end{array}$ & 48 & $48 \%$ & 16 & $40=47.6 \%$ & 16 & $8=50 \%$ \\
\hline
\end{tabular}




\begin{tabular}{|c|c|c|c|c|c|c|c|}
\hline 17 & $\begin{array}{l}\text { Participation in Schwartz Rounds or other } \\
\text { structured reflective discussion }\end{array}$ & 46 & $46 \%$ & 17 & $36=42.9 \%$ & 9 & $10=62.5 \%$ \\
\hline 18 & $\begin{array}{l}\text { Using the NMC Code in classroom sessions } \\
\text { (eg: post-registration students) or workshops } \\
\text { in workplace }\end{array}$ & 45 & $45 \%$ & 17 & $36=42.9 \%$ & 13 & $9=56.3 \%$ \\
\hline 19 & $\begin{array}{l}\text { Other suggestions: } \\
\text { - 'Mock' reflective discussions/ } \\
\text { confirmations } \\
\text { - 'Champions' to mentor those who } \\
\text { are anxious } \\
\text { - Formal integration within more } \\
\text { frequent reflective practice sessions } \\
\text { - Documents from the same } \\
\text { institution available as examples } \\
\text { - Protected CPD time } \\
\text { - A registrant-centred approach to } \\
\text { - } \text { selecting activities } \\
\text { The NMC to refrain from making } \\
\text { revalidation sound so complicated, } \\
\text { and easier to upload the information } \\
\text { - Development and support of a } \\
\text { clinical career pathway }\end{array}$ & 7 & $7 \%$ & 19 & $3=3.6 \%$ & 19 & $4=25 \%$ \\
\hline
\end{tabular}

Table 4: Ranking of activities which help prepare registrants for revalidation

Table 5 shows that across all categories of participants responding to a question about optimum times to introduce students to revalidation $(\mathrm{N}=107)$, the first and final years were identified. While $8(57.1 \% ; \mathrm{N}=14)$ midwifery participants favoured the first year, $49(52.7 \% ; \mathrm{N}=93)$ nursing respondents chose the third year; the latter option was particularly popular amongst students of both professions. It was suggested that links with curriculum 'activities' such as reflections, maintaining portfolios and providing feedback to registrants should be highlighted from the start of the programme. 'Preparation' needed to be meaningful, relevant and accurate and the 'purpose' needed to be clear. It was important for students to become familiar with the 'process' and language involved, developing good habits which would be ongoing throughout their careers:

"Ideally this should be student led but they should be revalidation ready on completion of the programme." (RMU4) 


\begin{tabular}{cllll} 
& Nursing $(\mathrm{N}=93)$ & Midwifery $(\mathrm{N}=14)$ & Registrants $(\mathrm{N}=\mathbf{7 3})$ & Students $(\mathrm{N}=34)$ \\
\hline First year & $\mathbf{3 6 ( 3 8 . 7 \% )}$ & $\mathbf{8 ( 5 7 . 1 \% )}$ & $\mathbf{3 6 ( 4 9 . 3 \% )}$ & $\mathbf{8 ( 2 3 . 5 \% )}$ \\
\hline Second year & $5(5.4 \%)$ & $0(0 \%)$ & $2(2.7 \%)$ & $3(8.8 \%)$ \\
\hline Third year & $\mathbf{4 9 ( 5 2 . 7 \% )}$ & $\mathbf{6 ( 4 2 . 9 \% )}$ & $\mathbf{3 4}(\mathbf{4 6 . 6 \% )}$ & $\mathbf{2 1}(\mathbf{6 1 . 8 \% )}$ \\
\hline After registration & $3(3.2 \%)$ & $0(0 \%)$ & $1(1.4 \%)$ & $2(5.9 \%)$ \\
\hline
\end{tabular}

Table 5: Suggested timing of introduction to revalidation in pre-registration curricula

\subsection{Thematic analysis:}

Layering of increasing levels of abstraction through inter-relation of codes and themes, as advocated by Cresswell and Poth (2018), was achieved through team discussion. Four key themes were identified. Throughout the survey 'Professional Values' were found to be central to a meaningful experience of revalidation for all stakeholders, comprising codes of 'professionalism and accountability', 'respect/ being valued' and 'appreciating differences'. The 'Process' was facilitated through adequate 'Preparation', which included appropriate 'activities' and adequate 'time'. 'Choice' of 'people' supporting the 'Process' enabled 'learning from others/experiences'. This avoided a 'tick-box' exercise and promoted achievement of the 'Purpose' of revalidation. A 'Conceptual Model of Revalidation with Professional Values at the Core' was developed to visually represent these concepts (Figure 2). The four main themes were located centrally, with arrows demonstrating their inter-relationship. Codes reflecting positive contributions to revalidation encircled these, coloured green to represent growth. Codes identified as hazardous to the experience of revalidation and its intended purpose were coloured amber and placed on the perimeter of the model. 


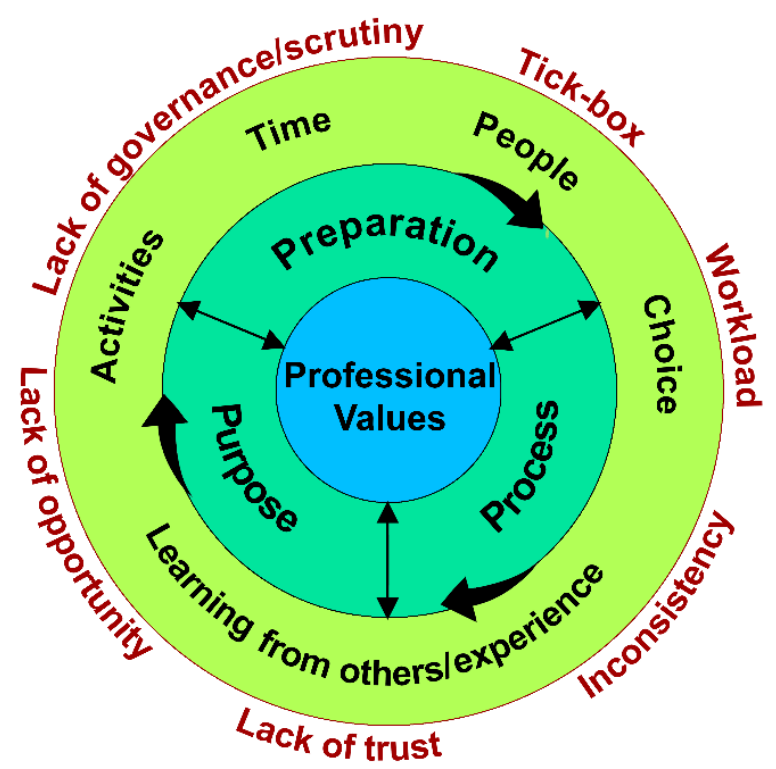

Figure 2: Conceptual Model of Revalidation with Professional Values at the Core

\section{DISCUSSION}

Views of NMC revalidation were, overall, positive - confirming findings by Ipsos MORI $(2017 ; 2018)$ and Attenborough and Abbott (2018a). Similarly, reflective elements and CPD were highly valued. The opportunity to share experiences with fellow registrants was identified as a particular strength of the process. The responsibility of employers to support registrants in maintaining their competence through CPD reiterated recommendations by ANCC (2012), Casey et al. (2017) and Lanlehin (2018).

A desire for external perspectives was evident in our study. Ipsos MORI $(2017 ; 2018)$ highlighted similar demand for credibility, transparency and regular verification by the NMC. In contrast, some registrants failed to engage sufficiently with the revalidation process and attempts at manipulation were likewise reported by Attenborough and 
Abbott (2018a). Some unfavourable comparisons were made with what was perceived as the more authentic and credible scrutiny of midwifery supervision, in which, prior to its dissolution a year after revalidation was introduced, annual reviews had been mandatory (NMC, 2017).

In the period April 2017 to March 2018, the NMC (2018) reported that $68.7 \%$ confirmations were undertaken by an NMC-registered line manager, $27 \%$ by an NMC registrant who was not the line manager, $3.5 \%$ by a non-registrant line manager and $0.8 \%$ by 'others'. The NMC (2019) currently recommends that confirmation is undertaken by line managers and aligned with appraisal. Our study, the national evaluation of medical revalidation (Archer et al., 2018) and Ipsos MORI $(2017 ; 2018)$ have, however, identified tensions in this approach. It can result in conflicts of interest, disparate agendas and a 'tick-box' process, in which the professional focus may not be central. Participants in our survey highlighted the benefits of incorporating the reflective discussion and confirmation in one meeting with a registrant of their choice; facilitating collegiate learning and maintaining the focus, while optimising resources. This is, however, only possible when the confirmer is also an NMC registrant. We therefore recommend that the latter should become mandatory, with employers supporting the revalidating nurse or midwife's choice of colleague.

Exploration of the student perspective and activities which promote preparation for, and engagement in, the revalidation process has addressed a gap in the literature. The anomaly of some nursing students incorrectly identifying that they had fulfilled the roles of 'reflective discussion partners' or 'confirmers' - suggesting misunderstanding of terminology - was of concern, as was the high proportion who did not know when 
they would first need to revalidate. Midwifery students seemed more prepared that nursing peers, although a lower response rate to this question from the latter limits interpretation. Attenborough and Abbott (2018b) explored perceptions of professional identity through semi-structured interviews of five nursing and midwifery students in another university, including a question about their knowledge of revalidation. All were able to explain the process, although some did not realise that educator roles fulfilled NMC practice requirements. These gaps in knowledge emphasise the importance of 'professional socialisation', which is facilitated through leadership of more experienced practitioners (Frankel, 2008). We therefore recommend that registrants in academic and clinical settings should role-model positive attitudes and encourage discussion about revalidation. Introduction in the first year and more focused preparation in the final year of pre-registration programmes is recommended. The links between revalidation and curriculum components which promote reflective scrutiny and continued learning need to be made explicit. Our conceptual model may contribute to understanding that the purpose extends beyond achievement of pre-registration programme requirements into future professional careers.

A number of limitations in this study restrict generalisability, although strengths are also evident. Researchers were based at one university, and participants were recruited from the same site and its associated clinical placements. Efforts were made to reduce bias by ensuring anonymity and triangulating independent data analysis. Collaboration with stakeholders and the team approach enhanced authenticity of research design and interpretation (Cresswell and Poth, 2018). Differences in quantitative findings between academic and clinical settings need to be interpreted with caution as proportionate representation of clinicians was much lower. The smaller 
numbers of midwifery participants also had greater impact when comparing professions (Faber and Fonseca, 2014). Although findings from open questions in a survey have limitations, qualitative responses from 80 registrants have contributed to the body of knowledge around NMC revalidation which is currently primarily quantitative (Ipsos MORI, 2018). The research team intends to undertake a second phase of the RRiP project to explore some of the findings in more depth through focus groups, including the reasons some registrants select an external RDP or confirmer. It is also recommended that qualitative research at national level is undertaken to compare experiences between professions and places of employment.

\section{CONCLUSIONS}

Findings from this survey corroborate many of those in the existing literature and add new insights by considering pre-registration preparation for revalidation. A model for a meaningful continuum of engagement from the pre-registration period through to professional careers has been developed. Essential to revalidation's success is an appreciation of the professional purpose of the process, valuing of individuals and awareness of potentially compromising factors. These principles may transcend international boundaries when considering maintenance of professional registration and competence. 


\section{REFERENCES}

Akamine, I., Uza, M., Shinjo, M., Nakamori, E., 2013. Development of competence scale for senior clinical nurses. Japan Journal of Nursing Science 10(1), 55-67. https://doi.org/10.1111/j.1742-7924.2012.00210.x

American Nurses Credentialing Center's Commission on Accreditation, 2012. The Value of Accreditation for Continuing Nursing Education: Quality Education Contributing to Quality Outcomes.

https://www.apna.org/files/public/Chapters/Chapter\%20Toolkit/ANCC\%20Accreditati on\%20White\%20Paper\%20-\%20Final\%2011\%2026\%202012.pdf (accessed 3/3/19)

Archer, J., Cameron, N., Lewis, M., Marshall, M., O'Hanlon, J., Regan de Bere, S., Walshe, K., Wilson, S., 2018. Evaluating the regulatory impact of medical revalidation for the General Medical Council. https://www.gmc-uk.org/Imedia/documents/umbrella-report-final pdf-74454378.pdf (accessed 3/3/19)

Attenborough, J., 2017. Enabling revalidation for registrants working in an education setting. Nursing Times 113(4), 34-35. https://www.nursingtimes.net/roles/nurseeducators/enabling-revalidation-for-registrants-working-in-an-educationsetting/7016620.article (accessed 3/3/19)

Attenborough, J., Abbott, S., 2018a. The impact of Nursing and Midwifery Council revalidation on the professional identity of academic staff in a higher education institution: A qualitative study. Nursing Open, 1-9. DOI: 10.1002/nop2.224 
Attenborough, J., Abbott, S., 2018b. Building a professional identity: views of preregistration students. Nursing Times [online] 114 (8), 52-55.

https://www.nursingtimes.net/roles/nurse-educators/building-a-professional-identityviews-of-pre-registration-students/7025170.article (accessed 3/319)

Boulet, J., van Zanten, M., 2014. Ensuring high-quality patient care: the role of accreditation, licensure, specialty certification and revalidation in medicine. Medical Education 48(1), 75-86. https://doi.org/10.1111/medu.12286

Casey, M., Cooney, A., O'Connell, R., Hegarty, J., Brady, A.M., Kennedy, C.M., O' Reilly, P., Heffernan, E., Fealy, G.M., McNamara, M., O'Connor, L., 2017. Nurses, midwives and key stakeholders' experiences and perceptions on requirements to demonstrate the maintenance of professional competence: An Irish Study. Journal of Advanced Nursing 73(3), 653 - 664. https://doi.org/10.1111/jan.13171

Cowan, D.T., Wilson-Barnett, J., Norman, I.J., 2007. A European survey of general nurses' self assessment of competence. Nurse Education Today 27(5), 452-458. https://doi.org/10.1016/j.nedt.2006.08.008

Creswell, J.W., Poth, C.N., 2018. Qualitative Inquiry and Research Design: Choosing Among Five Approaches. Los Angeles: SAGE.

Faber, J., Fonseca, L.M., 2014. How sample size influences research outcomes. Dental Press Journal of Orthodontics, 19(4), 27-29. doi: 10.1590/2176$\underline{9451.19 .4 .027-029 . e b o}$ 
Francis, R., 2013. Report of the Mid Staffordshire NHS Foundation Trust Public Inquiry

https://webarchive.nationalarchives.gov.uk/20150407084231/http://www.midstaffspub licinquiry.com/report (accessed 3/3/19)

Frankel, A., 2008. What leadership styles should senior nurses develop? (Extended article). Nursing Times 104(35), 23-24. https://www.nursingtimes.net/clinicalarchive/leadership/what-leadership-styles-should-senior-nursesdevelop/1811643.article (accessed 3/3/19)

Gill, F.J., Leslie, G.D., Grech, C., Latour, J.M., 2013. Using a web-based survey tool to undertake a Delphi study: Application for nurse education research. Nurse Education Today 33(11), 1322-1328. https://doi.org/10.1016/j.nedt.2013.02.016

Ipsos MORI, 2017. Independent evaluation of revalidation for Nurses and Midwives: Interim Report (Year One).

https://www.nmc.org.uk/globalassets/sitedocuments/annual reports and accounts/r evalidationreports/ipsos-mori-evaluation-report.pdf (accessed 3/3/19)

Ipsos MORI, 2018. Independent evaluation of revalidation for Nurses and Midwives: Interim Report (Year Two).

https://www.nmc.org.uk/globalassets/sitedocuments/annual reports and accounts/r evalidationreports/ipsos-mori-revalidation-evaluation-report-year-2.pdf (accessed $3 / 3 / 19)$ 
Lanlehin, R.M., 2018. Self-tracking, governmentality, and Nursing and Midwifery Council's (2016) revalidation policy. Nurse Education Today 64, 125-129, https://doi.org/10.1016/j.nedt.2018.01.033

Merkur, S., Mladovsky, P., Mossialos, E., McKee, M., 2008. Policy Brief: Do lifelong learning and revalidation ensure that physicians are fit to practise? World Health Organisation Regional Office for Europe, Copenhagen.

http://www.euro.who.int/ data/assets/pdf file/0005/75434/E93412.pdf (accessed $3 / 3 / 19)$

National Council of State Boards of Nursing, 2011. What You Need to Know about Nursing Licensure and Boards of Nursing.

https://www.ncsbn.org/Nursing Licensure.pdf (accessed: 3/3/19)

National Health Service England, 2013. Review into the quality of care and treatment provided by 14 hospital trusts in England: Overview report (Keogh report).

https://www.nhs.uk/NHSEngland/bruce-keogh-review/Documents/outcomes/keoghreview-final-report.pdf (accessed 3/3/19)

Nursing and Midwifery Council, 2017. Changes to midwifery supervision. https://www.nmc.org.uk/standards/midwifery/changes-to-midwifery-supervision/ (accessed 3/3/19) 
Nursing and Midwifery Council, 2018. Revalidation annual data report.

https://www.nmc.org.uk/globalassets/sitedocuments/annual reports and accounts/r

evalidationreports/revalidation-annual-data-report-year-2.pdf (accessed 3/3/19)

Nursing and Midwifery Council, 2019. How to revalidate with the NMC.

https://www.nmc.org.uk/globalassets/sitedocuments/revalidation/how-to-revalidate-

booklet.pdf (accessed 30/5/19)

\section{ACKNOWLEDGEMENTS}

The contribution of Rusalka Clarke, final year mental health nursing student at the time of the project, in assisting in the development of the 'Conceptual Model of Revalidation with Professional Values at the Core' is acknowledged. The research team would also like to thank all the midwifery and nursing colleagues and students who took the time to respond to the survey.

Declarations of interest: none

This research did not receive any specific grant from funding agencies in the public, commercial, or not-for-profit sectors.

Ethical approval: University Faculty Research Ethics Committee ref no: 16/17-758 
